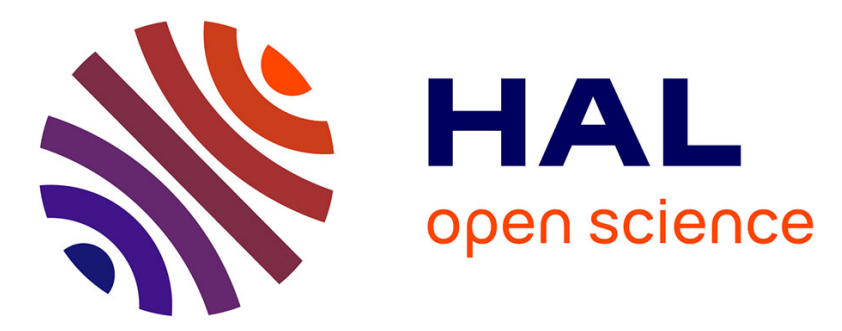

\title{
Mitigation of enteric methane for French cattle: potential extent and cost of selected actions
}

Michel Doreau, Laure Bamière, Sylvain Pellerin, Michel Lherm, Marc Benoit

\section{To cite this version:}

Michel Doreau, Laure Bamière, Sylvain Pellerin, Michel Lherm, Marc Benoit. Mitigation of enteric methane for French cattle: potential extent and cost of selected actions. Joint ISNH/ISRP International Conference 2014: Harnessing the Ecology and Physiology of Herbivores, Sep 2014, Canberra, Australia. 2014. hal-01173065

\section{HAL Id: hal-01173065 \\ https://hal.science/hal-01173065}

Submitted on 3 Jun 2020

HAL is a multi-disciplinary open access archive for the deposit and dissemination of scientific research documents, whether they are published or not. The documents may come from teaching and research institutions in France or abroad, or from public or private research centers.
L'archive ouverte pluridisciplinaire HAL, est destinée au dépôt et à la diffusion de documents scientifiques de niveau recherche, publiés ou non, émanant des établissements d'enseignement et de recherche français ou étrangers, des laboratoires publics ou privés. 


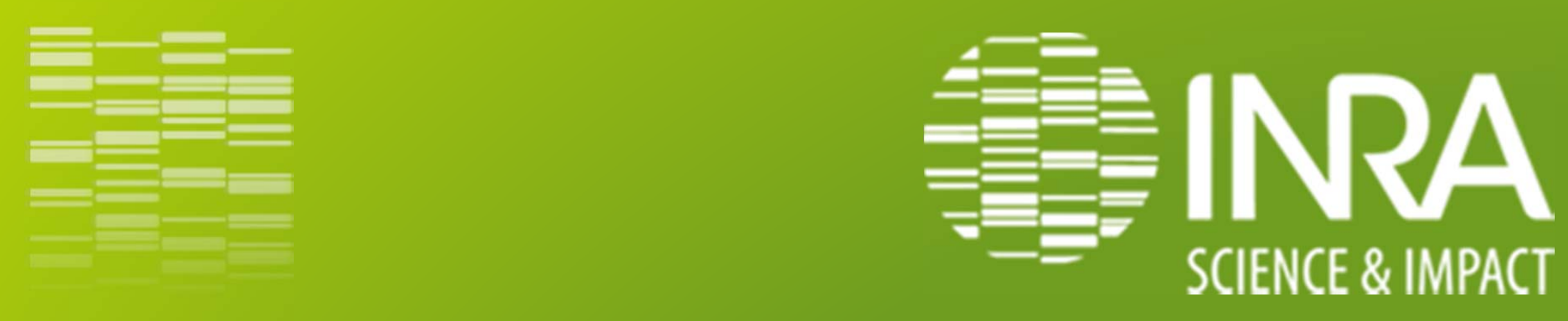

VetAgro Sup

A)

Mitigation of enteric methane for French cattle : potential extent and cost of selected actions

\section{Michel DOREAU, Laure BAMIERE, Sylvain PELLERIN, Michel LHERM, Marc BENOIT}

Herbivores Research Unit - Clermont-Ferrand

Public Economy Research Unit - Versailles

Environment and Agronomy Division - Bordeaux 


\section{The statement}

Livestock sector accounts for $14.5 \%$ of anthropogenic greenhouse gases (GHG) emissions (FAO, 2013)

Public policies aim to decrease GHG emissions

Scientific community works at finding ways for GHG mitigation

How to bridge the gap between scientists and policy makers ?

$\Longrightarrow$ Determine the best available and applicable mitigation techniques

$\Longrightarrow$ Determine the extent of abatement and the cost 


\section{The French government order}

Propose 10 mitigation actions for French agriculture, evaluate effectiveness, calculate abatement extent and cost from now on until 2030

This presentation: action for decreasing enteric methane

$$
\text { (> 50\% GHG) }
$$

\section{Constraints}

$\Longrightarrow$ No change in production

No adverse effects on other sustainability issues

$\Longrightarrow$ No significant changes in farming systems but changes in practices

$$
\text { i.e. not business-as-usual Eenetiemerit- }
$$

$\Longrightarrow$ Proof of effectiveness, availability at present Acceptability by farmers and citizens inores 


\section{Selected actions and methodology}

\section{Dietary fats (unsaturated) Nitrates as dietary additives \\ Guyader et al., 2014}

Fats Extruded linseed and rapeseed

$3.5 \%$ additional fat

for a $14 \%$ methane abatement All cattle receiving concentrates
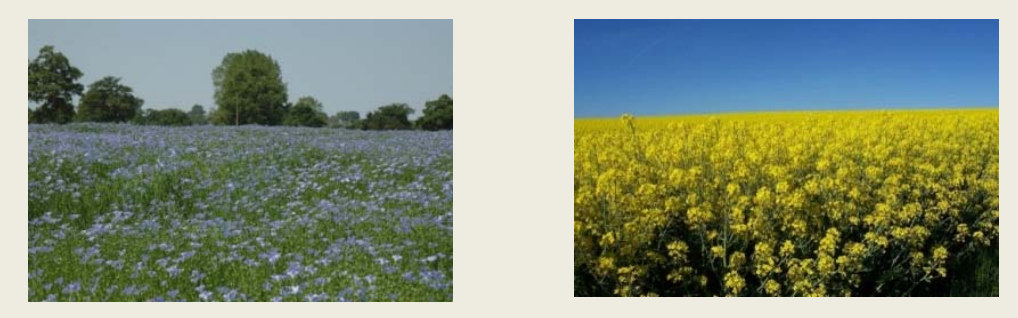

Replacement of cereals and meals Rapid adoption

Nitrates $1 \%$ in the diet for a $10 \%$ methane abatement

Only for cattle fed diets low in fermentable $\mathbf{N}$ (maize silage-based)

Replacement of other fermentable $\mathbf{N}$ sources (urea)

Slow and incomplete adoption

Abatement extent ( $\mathrm{t} \mathrm{CO}_{2}$-eq/yr) calculated from: Number of animals / yr kg of nitrate / animal abatement / kg nitrate 


\section{Abatement and cost}

FAT NIT

Abatement potential ( $\mathrm{Mt} \mathrm{CO}_{2}$-eq) $\quad 27.0 \quad 4.5$

Total cost for farmers (M€)

7209

170

Cost per $\mathrm{t} \mathrm{CO}_{2}$-eq avoided

High sensitivity to hypotheses for unitary emissions (per cow) for prices 


\section{Marginal abatement cost curve :}

\section{FAT \& NIT among all actions for agricultural GHG}

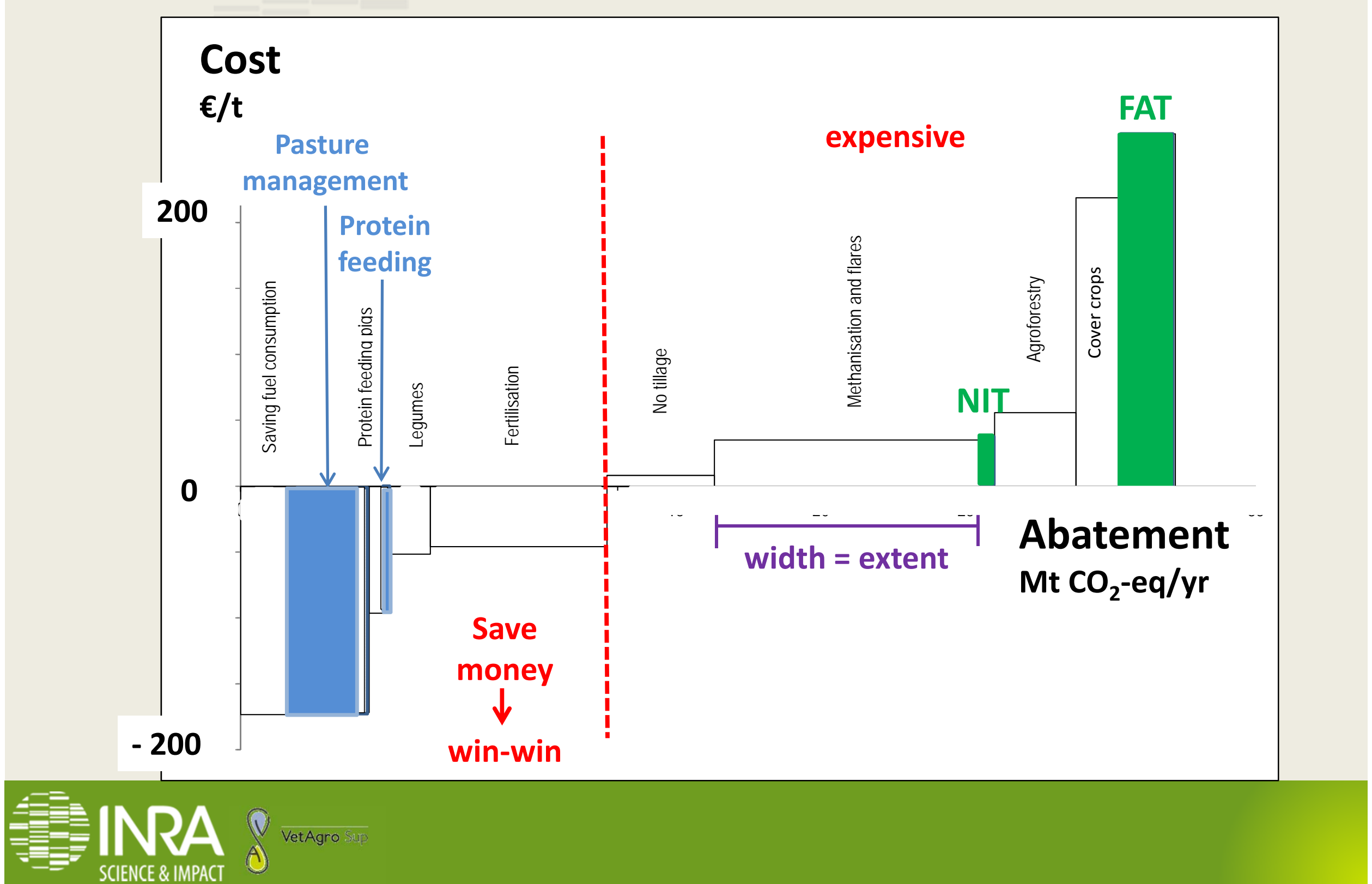




\section{Concluding remarks}

$\Longrightarrow$ Selection of options depends on initial constraints

$\Longrightarrow$ A significant methane abatement is possible now but may need incentives for application by farmers

$\Longrightarrow$ Other options may be possible in a near future Decisive role of policy makers

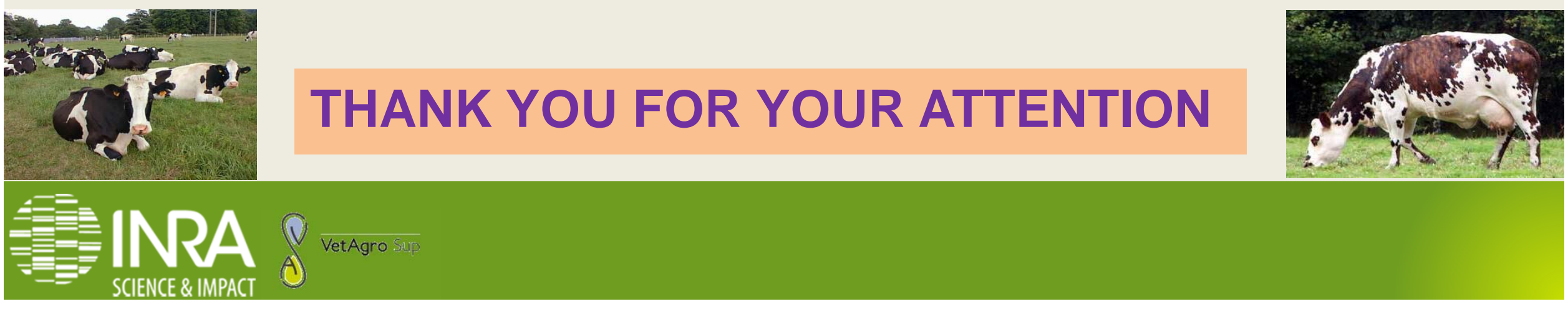

